\title{
Research of the Marketing Management in New Era Based on Enterprise Innovation
}

\author{
Huihui Gui \\ Wuchang University of Technology, Wuhan 430223, China.
}

Keywords: new era; corporate marketing management; innovation

Abstract: With the rapid economic development, our country's small and medium-sized enterprises began to push themselves to the public under the influence of the new normal economy. We are all in a new era of "Internet+". In response to the development of the "Internet+," China's Ministry of National Defense has also raised the "Internet+" plan to the national strategic level. The integration of the Internet and various industries enables every tiny individual to connect together. With the advent of the new era, the market environment has undergone tremendous changes. Enterprises no longer rely solely on their own internal forces, but more on strengthening external public power to achieve further development. For traditional enterprises, at this time, it is necessary to change the growth strategy by examining the situation and carry out a deeper round of growth in the new phase. China's Internet is in an era of vigorous development. For all areas of strong demand for big data, big data management segment is a breakthrough for corporate marketing.

\section{Introduction}

China has 30 years of reform and opening up. In the context of China's "mass entrepreneurship, innovation" and comprehensive deepening of reform and opening up. When China entered the new normal economy in 2015, the new economic normal has now become a hot topic in the community. In this social development, we have started the era of "Internet+". With the advent of the Internet era, many enterprises have seized this opportunity to develop rapidly. In this, big data management tools can promote marketing to be healthy and healthy. Long-term development [1].

\section{Integration of IT and Management Innovation}

\subsection{Significance of IT for Enterprise Innovation}

At present, the whole world has begun to enter the information age. We all use the Internet for liaison and shopping. Now that the Internet age has fully entered our lives, we must use the Internet in everything we do in life and become an integral part of our lives. Due to the needs of our lives, information technology and the information industry have been greatly improved and developed. The innovation and integration of IT and enterprise management model will change the traditional concept of the enterprise and will also allow the management of the enterprise to change from an extensive management approach to a refined management approach. Our country has already become 
a big manufacturing country through economic development. In the current era, our country's enterprises need to transform from manufacturing to "intellectualism," and the integration of IT and management innovation is the foundation. In the information age, information technology can be used to achieve business optimization and rational allocation of resources among enterprises, and a platform for information sharing and resource sharing. The integration of IT and management innovation provides ideas for the transformation of "intellectualism" of enterprises, and it also grasps the trend of common development of theory and technology [2], which has important practical significance for promoting the substantial advancement of manufacturing in China.

\subsection{E-commerce and Retail in China}

The world is now in the new round of scientific and technological revolution. The combination of the Internet and various fields is an essential link. In China's retail industry, there is also a wave of upsurges. Before the traditional retail industry in our country as a tertiary industry, daily to meet the material needs of our people. The scale of retailing in our country is huge, but the growth rate is slow. Under the integration of IT and enterprise management, under the trend of the Internet era, China's Internet technology and applications have been greatly promoted and developed, thus promoting the integration and development of the Internet and snack food industry. For the integration of the Internet and the retail industry, the interpretation in the definition is e-commerce [3]. E-commerce is a new term in the modern era that allows consumers and businesses to purchase and negotiate products online. E-commerce has broken down the traditional sales methods. The characteristics of e-commerce are: breakthroughs in space-time constraints, low costs for merchants, and providing consumers with more goods and materials for comparison, optimizing consumer decision-making and talent structure differentiation. In the e-commerce, more IT talents and network sales talents are accepted, thus making the talents more closely to the development of the modern era. In the current era, great changes have taken place in China's consumers' willingness and behavior: diversification of needs, changing roles, diverse purchasing methods, changes in the structure of consumers, diversification of channels for receiving information, and purchasing habits. Change. The change in the structure of the "Internet+" retail industry is just enough to meet the needs of consumers. This is also a trend. The State Council issued the "Guiding Opinions of the State Council on Actively Promoting the "Internet Plus" Initiative." Its significance is to accelerate the deep integration of Internet innovation achievements and various areas of society. With the support of sound laws and regulations and related policies, we will make full use of national policies to promote the healthy development of China's "Internet Plus" retail industry [4].

\subsection{Factors of Corporate Transformation}

In the current society, the transformation of enterprises has become an indispensable hot topic. In the manufacturing industry, some companies have begun to imitate innovation to carry out production, and in the production of the industry chain to improve their own product quality. In our country's enterprises, we should take the path of independent innovation. While constantly self-technological innovation and management innovation, we should also enhance the interaction between government and enterprises and the cooperation between enterprises. Develop their own brand strategy, so as to enhance the company's core competitiveness and achieve sustainable corporate battles. The transformation of enterprises also requires some opportunities, including: the determination of high-level internal corporate change, the timing of the transformation of the enterprise for the times, and the strategies for the formulation and transformation of enterprises. These three are three important factors in the transformation of enterprises. China is currently a big 
manufacturing country, but on the way to becoming "China's intellectual creation," independent innovation to establish its own brand is a necessary path. In the process of transformation, we are not only making changes in technology.

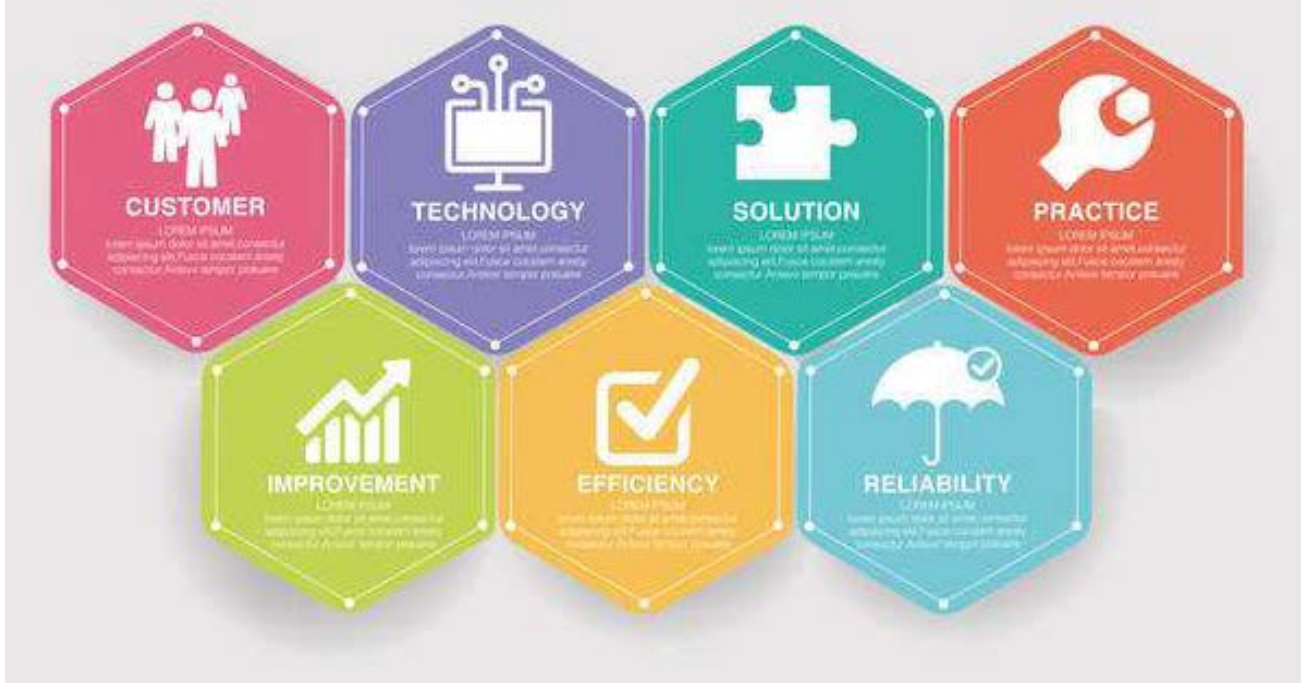

Fig. 1 Seven Elements of Enterprise Marketing Management Innovation

We also need to make continuous progress in service improvement and management systems and achieve new milestones. The management of the enterprise is the guarantee of achieving the strategic goal. The decision-making level of the enterprise has a greater influence on the activities of the enterprise, and the things that the decision-making layer attaches importance to can be completed efficiently. In the development of the company, it needs a stable system and a stable core technology and management team. Talent is also a major factor in the transformation of enterprises. In today's society, whoever has talents has achieved the first opportunity. Talent is an indispensable resource for enterprise development. The development of the enterprise is a social behavior. We should attach importance to the social environment. This is also a major environmental factor. Important factors in the transformation and development of enterprises: technological factors, talent factors, management factors, and social environmental factors.

\section{Problems of Current Corporate Marketing Management in China}

\subsection{The Lack of Management Work}

In the further development of information technology, the space for expanding the business of the enterprise has been expanded, and the level of service capabilities has increased. The competition in the market is getting more and more severe. Now companies are beginning to face enormous challenges. In this era, if you don't want to be overwhelmed by fierce competition, use information to innovate in marketing management, and integrate and disperse traditional marketing management. In the enterprise's sales management innovation reform, there is a lack of work in marketing management. In the marketing management work of our country's enterprises, only a part of the companies will formulate plans for the company's marketing management from the perspective of strategic planning. The lack of awareness of strategic planning in enterprise management in our country adds great difficulty to the optimization of marketing management. In China's marketing management, there is no reasonable division of functions and powers, which poses problems for the integration and optimization of marketing management, and affects the development of marketing 
management optimization.

\subsection{Marketing Management Mechanism and Staff Issues}

China's marketing management puts the cost element first. Under the influence of this idea, we will forget to establish a risk prevention mechanism for enterprises. For enterprises, losing a risk defense mechanism means losing a wall that resists storms. This is not good news for enterprises. . And in the marketing management industry, the fluctuations in the industry performance are affected by the social impact. Therefore, enterprises can guarantee the further development of marketing management only by establishing a risk resilience mechanism. As for the development of enterprises, talent is also a major factor. An excellent system and idea requires talents to operate and implement. Nowadays, the team for marketing management is constantly expanding, but there is a serious shortage of talents in management. On the whole, only the person who executed the order is missing the person who made the plan. This is a challenge for the development of marketing management. Without good marketing management personnel, there is no scientific guidance for the team. The consequence of this result is that the effectiveness of marketing management is not good.

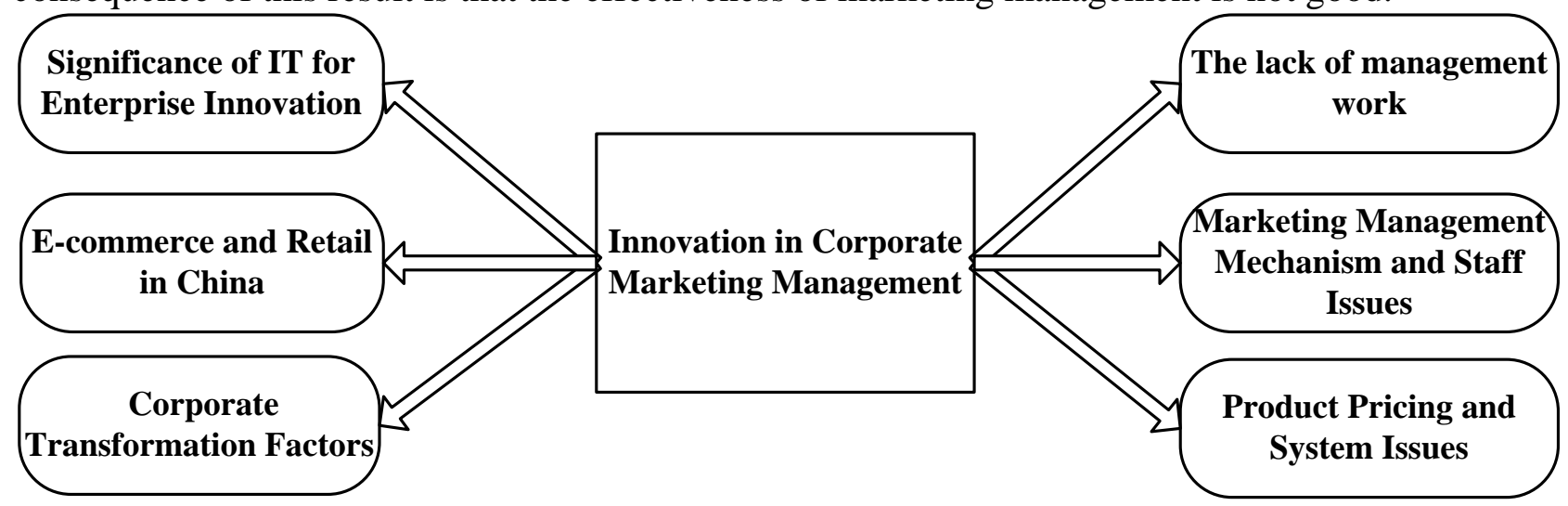

Fig. 2 The Innovation of Enterprise Marketing Management in the New Period

\subsection{Product Pricing and System Issues}

In marketing, the emphasis on quantity is too serious. In some companies, the traditional marketing model and thinking are deeply ingrained, and it is difficult to change for a time. In the actual sales of enterprises, the importance of the "quantity" assessment is far greater than "quality". At present, our country is the Internet age. As a result, companies use some unrealistic practices in the marketing process to attract consumers' attention. Consumers find false propaganda after use, which leads to a decline in the reputation of the product. And the management of the company after sales is lax. For the management of missing systems and measures with clear penalties and rewards, employees' enthusiasm is low and consumers' impressions are not good. This has affected the results of corporate marketing. In the information age, the quotes for product uploads are transparent on the Internet. In the competition between companies, price wars are inevitable. Utilizing consumers' esteem for prices, they began to cut prices to draw consumers' attention. In a fierce commercial struggle, lowering the price without a lower limit can increase the number of orders, but it also reduces the profitability of the company. Blindly reducing prices will not bring benefits, but will only disrupt the market order. In the process of enterprise development, the management system is crucial. The establishment of a sound corporate marketing system and system is a must for an enterprise. In many companies, there are specialized marketing management departments, but these departments do not really fulfill their responsibilities and obligations in the work, as if they were in name only. It is 
even harder to find in small businesses, which is also an obstacle to the management change of corporate marketing.

\section{Innovative Measures for Corporate Marketing Management in The New Era}

\subsection{The Transformation of Corporate Management Philosophy}

In the development of the company, the purpose of carrying out marketing work is to strengthen the real promotion and promotion of the product, adhere to the "positive energy" enterprise marketing management model, so that products can increase sales, thereby improving the company's profitability, and achieve profitability goals. In changing thinking and changing the traditional sales philosophy, it is not only the sales personnel's ideological changes, but also the company's deep-level changes from the top to the bottom. This can only be done with half the effort, and it can really make a difference in marketing management thinking. While setting up the right marketing concept, companies should clearly understand that when designing a marketing plan, they should take into account the needs of consumers and understand that consumers are the core of the marketing plan. Before formulating a plan, you should be able to understand and be good at discovering various requirements of customers. Be sure to work toward not only meeting the physical needs of customers but also meeting the spiritual needs of customers. Both the sales process and post-sales questionnaires must strengthen communication with consumers so as to tap the upcoming demand in the current market and market. In order to occupy the marketing high ground in advance. From the consumer's needs to develop reasonable innovation and formulate a scientific marketing program, based on the long-term development of the company. It lays the foundation for the sustainable and stable development of the company.

\subsection{Establish and Improve Enterprise Marketing Management System}

In the enterprise, there is a management department and it also has a certain marketing system. However, in some enterprises, management departments and management systems do not feel for employees, and they feel that there is a low level of presence. This shows that the management department in the use of their own authority to implement the management system formulated by the company is not strict enough to perform due diligence. This is all that needs to be improved and supplemented. Employees are required to fully comply with the management system. The division of sales personnel and their own functions should be clearly identified. It is employees who understand what they should do and improve their work efficiency. Establish a supervision agency to supervise the human executive ability of the management department so as to supervise each other and improve the efficiency of the system and regulations that govern the marketing personnel of the company. For the marketer to set a clear system of rewards and penalties, it is not sufficient to use only the sales volume as a standard for salary management. Should be examined in many aspects, in addition to the amount of sales but also take into account other assessment results for summary. Refining the salaries of marketing management departments. For marketing managers, this will enable them to motivate their work. For the salesman to carry out many rigorous assessments and evaluations, it is not enough to pay attention to the sales volume in the assessment, and it is necessary to increase the assessment of the ideology, awareness and behavior of the marketing personnel. It is also crucial for the customer's evaluation of the salesperson. It is necessary to improve the assessment and evaluation, and thoroughly examine the marketing personnel. It can also improve the quality of sales staff and maintain a good image in front of customers. 


\section{Conclusion}

In the current stage, the rapid development of information technology has driven the deep development of the market economy, and the traditional marketing model of Chinese enterprises has been impacted, and this is a relatively large challenge. To do a good job in corporate marketing is inseparable from the orderly support of the marketing department, to pay attention to changes in its own marketing management concept, to make full use of the resources of the information age, for corporate marketing efforts, in the market for the company's competition The advantages laid the foundation.

\section{References}

[1] Ou Shuyang, Yuan Hong, et al. Innovation: The Vitality of Marketing. Journal of Southwest Agricultural University (Social Sciences Edition), Vol. 2 (2004).

[2] Zheng Yuxiang, et al. Marketing Innovation: Strategic Choice of Chinese Enterprises in the Century. Journal of Liaoning University (Philosophy and Social Sciences), Vol. 3 (2001).

[3] (United States) Philip Kotler, et al. Marketing Management. Renmin University of China Press, (2001).

[4] He Yun, Lu Taihong, et al. New Trend of Marketing Management: An Analysis of Performance Marketing Research. Foreign Economics and Management, Vol. 1 (2011). 